\title{
Impact of phosphate solubilizing bacteria on wheat (Triticum aestivum) in the presence of pesticides
}

\author{
I. Munir ${ }^{a}$, A. Bano ${ }^{a}$ and M. Faisal ${ }^{a *}$ (D) \\ aDepartment of Microbiology and Molecular Genetics, University of the Punjab - PU, Lahore, 54590, \\ Quaid-e-Azam Campus, Pakistan \\ *e-mail: mohdfaysal@yahoo.com
}

Received: November 19, 2016 - Accepted: May 5, 2017 - Distributed: November 30, 2018

(With 3 figures)

\begin{abstract}
Three phosphate solubilizing bacteria were isolated and identified by 16S rRNA sequencing as Pseudomonas putida, Pseudomonas sp and Pseudomonas fulva. The strains were subjected to plant biochemical testing and all the PGPR attributes were checked in the presence of pesticides (chlorpyrifos and pyriproxyfen). The phosphate solubilizing index of strain Ros2 was highest in NBRIP medium i.e $2.23 \mathrm{~mm}$. All the strains showed acidic pH (ranges from 2.5-5) on both medium i.e PVK and NBRIP. Strain Ros2 was highly positive for ammonia production as well as siderophore production while strain Rad2 was positive for HCN production. The results obtained by the strains Rad1, Rad2 and Ros2 for auxin production were 33.1, 30.67 and $15.38 \mu \mathrm{g} \mathrm{ml}^{-1}$, respectively. Strain Rad1 showed 16\% increase in percentage germination in comparison to control in the presence of pesticide stress. Most promising results for chlorophyll content estimation were obtained in the presence of carotenoids upto $6 \mathrm{mgg}^{-1}$ without stress by both strains Rad1 and Rad2. Study suggests that especially strain Ros2 can enhance plant growth parameters in the pesticide stress.
\end{abstract}

Keywords: Pseudomonas, phosphate solubilizing bacteria, siderophore production, chlorpyrifos, pyriproxyfen.

\section{Impacto das bactérias solubilizantes de fosfato no trigo (Triticum aestivum) na presença de pesticidas}

\section{Resumo}

Três bactérias solubilizantes de fosfato foram isoladas e identificadas por seqüenciamento de rRNA 16S como Pseudomonas putida, Pseudomonas sp e Pseudomonas fulva. As estirpes foram submetidas a testes bioquímicos de plantas e todos os atributos PGPR foram verificados na presença de pesticidas (clorpirifos e piriproxifeno). O índice de solubilização de fosfato da estirpe Ros2 foi mais elevado no meio NBRIP, isto é, 2,23 mm. Todas as estirpes apresentaram um pH ácido (varia de 2,5-5) em ambos os meios, isto é PVK e NBRIP. A estirpe Ros2 foi altamente positiva para a produção de amoníaco, bem como a produção de sideróforos enquanto a estirpe Rad2 foi positiva para a produção de HCN. Os resultados obtidos pelas estirpes Rad1, $\operatorname{Rad} 2$ e $\operatorname{Ros} 2$ para a produção de auxina foram 33,1, 30,67 e $15,38 \mu \mathrm{g} \mathrm{ml}{ }^{-1}$, respectivamente. A deformação Rad1 mostrou aumento de $16 \%$ na germinação percentual em comparação com o controlo na presença de stress de pesticida. Os resultados mais promissores para a estimativa do teor de clorofila foram obtidos na presença de carotenóides até $6 \mathrm{mgg}^{-1}$ sem estresse por ambas as cepas Rad1 e Rad2. Estudo sugere que especialmente a estirpe Ros2 pode melhorar parâmetros de crescimento de plantas no estresse de pesticidas.

Palavras-chave: Pseudomonas, bactérias solubilizantes de fosfato, produção de sideróforos, clorpirifos, piriproxifena.

\section{Introduction}

Plant growth promoting rhizospheric bacteria has been used for decades in horticulture and agriculture for the improvement and productivity of crops. Biodiversity pays role in the maintenance of ecosystem, it includes variety of living organisms and genetic diversity of species (Alho, 2008). Some PGPR exert advantageous effects on the plants by the process of nitrogen fixation by delivering combined nitrogen to the plant (Jetiyanon, 2015). Microorganisms perform an important role in increasing root growth, germination rate, leaf surface area water and mineral uptake percentages, crop yield and tolerance or resistance to stresses. Nitrifying and denitrifying microbes have great impact on ecosystem that it mediates nitrogen cycle (Medeiros et al., 2014). The most common bacterial genera involved in PGPR are Bacillus, Azospirillum and Burkholderia (Mangmang et al., 2015). Iron, nitrogen and phosphorous are important components for all life forms. Bacteria solubilize phosphorous which can be the substitute 
of synthetic phosphatic fertilizers (Ahemad and Kibret, 2014). Bacteria require iron for the chelation process and form siderophore complex. Phosphate solubilization and transport of ferric iron by siderophore released from PGPR increases the accessibility of different types of nutrients in the rhizosphere (Jetiyanon, 2015).

The area of soil near the root system is termed as rhizosphere (Ahemad and Kibret, 2014). Plants produce phytostimulators which increase the growth of plants, mostly cytokinins, indole-3-acetic acid (IAA), gibberellins, auxins and ACC deaminase (Abbamondi et al., 2016). Some microorganisms release 1-aminocyclopropa ne-1-carboxylate (ACC) deaminase enzyme which produces $\alpha$-ketobutyrate and ammonia from ACC. It decreases ethylene level in the plant which helps in the elongation of roots formation and improvement in seedlings survival. Indole-3-acetic acid (IAA) released from PGPR changes root growth and morphology as it facilitates plant's nutrient uptake potentials (Jetiyanon, 2015). Usually the mechanisms used by the PGPR are for the enhancement of growth, but in stress conditions, strains mostly do not perform their functions efficiently because they have to compete in the harsh environment. However, many PGPR strains are able to tolerate the condition of stress and also have the ability to stimulate the growth of plants in stressful milieus (Parray et al., 2016). Microorganisms while living in pesticide stress, develop resistance to it. These microorganisms can effectively be used for bioremediation of pesticides contaminated sites along with their plant growth promoting attributes (Ahmad et al., 2015). Pesticides stress have been commonly applied to plants fruits, crops and vegetables for the protection all around the world. These pesticides due to persistence in the soil and also through direct exposure, harm the activities of bacteria which are able to solubilize phosphate. PSB Pseudomonas putida was observed for reduction in the phosphate $(\mathrm{P})$ activity. Among all the pesticides, chlorpyrifos had minimum detrimental effect and can be used in the agricultural field (Kumar et al., 2015). The present study was conducted to evaluate the effect of pesticides on wheat. The pesticides chlorpyrifos and pyriproxyfen were chosen for this study as these were commonly used in Pakistan to control the pests, also it enhances crop productivity.

\section{Materials and Methods}

\subsection{Sample collection and bacterial isolation}

Different soil samples were collected in the sterile bags from the rhizosphere of different plants. After collection, these samples of soil were processed for the isolation of bacteria able to solubilize phosphate. After making serial dilutions the samples were spread on agar plates. The isolation of bacteria able to solubilize phosphate was done on Pikovskaya's agar (PKV) (Pikovskaya, 1948).
Three phosphate solubilizing bacterial strains giving clear zones around the bacterial growth were selected for further analysis.

\subsection{Identification by $16 S$ rRNA gene sequencing}

The 16S rRNA gene sequencing was carried out by Macrogen, Korea. After trimming the sequences was BLAST analyzed (National Center for Biotechnology Information) in order to find the similarities between sequences. Phylogenetic trees were constructed by using $M E G A 4$ software by a neighbor-joining method, estimating the relationship between the halotolerant strains and reference strains.

\subsection{Determination of phosphate solubilization index}

$0.1 \mathrm{~mL}$ of each fresh bacterial culture was mixed in sterile distilled water and was placed on Pikovskaya, agar plates (Pikovskaya, 1948) and incubated for 7 days. By using formula, solubilization Index was measured.

\subsection{Phosphate estimation}

PVK medium and NBRIP liquid medium was used for the estimation of the activity of bacterial strains for phosphate solubilization. $1 \mathrm{ml}$ of $24 \mathrm{~h}$ bacterial suspension was added to each flask. All transfers of bacterial culture were carried out aseptically in triplicates and incubated at $28{ }^{\circ} \mathrm{C}$ on a shaker for 7 days. After centrifugation of samples, the supernatant was filtered and the filtrate was used for quantification of soluble Phosphate (Jackson, 1973)

\subsection{Effect of phosphate solubilization on pH titrable acidity}

$\mathrm{pH}$ meter was used to determine $\mathrm{pH}$ change in the medium after following 7 days incubation due to the growth of phosphate solubilizing bacteria. Seven days old bacterial cultures were checked for the titrable acidity and centrifugation of culture medium at $1000 \mathrm{rpm}$ was carried for 10 minutes. Five millilitre of supernatant was titrated against $0.01 \mathrm{~N} \mathrm{NaOH}$ with a few drops of phenolphthalein indicator consumed per $5.0 \mathrm{ml}$ of culture filtrate.

\subsection{PGPR Attributes}

\subsubsection{Ammonification}

Ammonia production for all the isolates was checked following manual methods (Cappuccino and Sherman, 2005). Freshly grown bacterial culture was inoculated in peptone broth and incubated at $30 \pm 0.1{ }^{\circ} \mathrm{C}$ for $48 \mathrm{~h}$ in incubator shaking was done. $0.5 \mathrm{ml}$ of Nessler's reagent was added in the test tubes after incubation. Color change was observed from faint yellow to dark brown

\subsubsection{Hydrogen cyanide production}

Production of hydrogen cyanide (HCN) from the bacterial isolates was observed as per methodology observed by Castric and Castric (1983). Development of light brown color was observed which indicated positive results for $\mathrm{HCN}$ production. 


\subsubsection{Siderophores production}

Chrome azurol sulfonate assay agar was used for the siderophores production (Schwyn and Neilands, 1987). In order to observe qualitative assay, bacterial cultures were spotted onto the blue agar and incubated at $28^{\circ} \mathrm{C}$ for $24-48 \mathrm{~h}$. Color change was observed for the interpretation of results, ferric ion was transferred from strong blue complex to the siderophore. Yellow- orange zones around the growth indicated positive results for siderophore production.

\subsubsection{Auxin estimation}

Fresh bacterial cultures were inoculated in the fifty milliliter of L-broth containing $0.1 \%$ L-tryptophan and incubated in shaker at conditions $30 \pm 0.1{ }^{\circ} \mathrm{C}$ and $180 \mathrm{rpm}$ for $48 \mathrm{~h}$ in the dark. Cultures were centrifugated at $10,000 \mathrm{rpm}$ for $10 \mathrm{~min}$ at $4{ }^{\circ} \mathrm{C}$. Colorimetric assay was used for the estimation of Indole-3-acetic acid (IAA) in the supernatants by adding $2 \mathrm{ml}$ of Salkowski reagent in $1 \mathrm{ml}$ of the supernatent. Pink color was observed and absorbance after $30 \mathrm{~min}$ at $535 \mathrm{~nm}$ in UV/Visible Spectrophotometer was read (Gordon and Weber, 1951). Regression equation was used to calculate IAA production from the standard curve and the result was expressed as $\mu \mathrm{g} \mathrm{ml}^{-1}$ in comparison to control.

\subsubsection{ACC deaminase}

Following the method of (Penrose and Glick, 2003), ACC deaminase activity for phosphate solubilizing bacteria was observed.

\subsection{Effect of pesticide stress on root elongation assay}

The effect of bacteria able to solubilize phosphate on growth of wheat plant was observed under pesticide stress. For this purpose watman filter paper was fitted in the petri plates. After autoclaving plates were labelled for each strain and treatment. Inoculated seeds were evenly spread in petri plates by sterile forceps. All the plates were placed in the dark for three days. Germination was observed regularly. Plates seedlings were allowed to grow in the light after germination for 10 days and parameters were recorded.

\subsection{Field experiment with wheat plant}

Fresh fertile soil was taken from the field of New Campus, University of the Punjab, Lahore, Pakistan. Soil was moist and brown in color. About 7-8 kg of soil was filled in each labeled pot properly. Soil was also mixed with a combination of pesticides as per recommended. Healthy seeds of Wheat (Triticum aestivum) were selected for experiment. Seeds were rinsed with tap water, discarded the floating (defective seeds) and proceeded with the healthy seeds. The seeds were dipped in $0.1 \% \mathrm{HgCl}_{2}$ solution for 5 minutes and were 3-5 times washed with sterilized water for complete elimination of $\mathrm{HgCl}_{2}$ traces. The impact of phosphate solubilizing bacteria on wheat plant was observed under the stress condition i.e., pesticide stress. The three strains were observed with 3 treatment groups. Treatment group 1, 2 and 3. Treatment group 1 contained pesticide chlorpyrifos, treatment group 2 contained pesticide pyriproxyfen while treatment group 3 contains the combination of both pesticides (chlorpyrifos and pyriproxyfen). All these 3 treatments were compared with the control in which no pesticide was used. Seeds were sown in pots labeled with respective strains. The clean conditions were maintained during sowing. Ten seeds per pot were sown with the help of forceps. The optical density of bacterial culture for inoculation was adjusted to 0.5 at $600 \mathrm{~nm}$ and $10 \mathrm{ml}$ of this bacterial suspension was added to soil. Pots were watered equally on daily basis up-to maturation of plants. Thinning of the plants was carried out after two months and only five plants which were left to grow in each pot were selected. After thinning plant material was used for biochemical analysis.

\subsection{Plant biochemical assay}

\subsubsection{Chlorophyll content}

For the estimation of photosynthetic pigments $100 \mathrm{mg}$ of fresh leaf material was homogenized with acetone $(80 \%)$. The homogenate volume was kept at $10 \mathrm{ml}$ and filtered to remove the plant material. The absorbance of extracted pigments was read using UV spectrophotometer at different wavelengths $(470,645$ and $663 \mathrm{~nm})$ following Arnon (1949) method.

\subsubsection{Free Proline content determination}

Fresh leaves of wheat plant (Triticum aestivum) were trimmed to smaller pieces. Proline concentration in leaves was determined by triturating frozen leaves of plants. Subsequently $500 \mathrm{mg}$ of triturated leaf material was mixed in $5 \mathrm{ml}$ of $3 \%$ sulfosalicylic acid. After centrifugation the supernatant was mixed in equal proportions $(1: 1: 1)$ with glacial acetic acid and ninhydrin. After heating the reaction mixture at $100{ }^{\circ} \mathrm{C}$ in a boiling water bath for $60 \mathrm{~min}$, the reaction mixture was cooled to room temperature and development of brick red colour was observed. Toluene was added to the above mixture and moved to a separating funnel and mixed thoroughly. Layer containing chromophore $\mathrm{x}$ was separated and its optical density at $520 \mathrm{~nm}$ was measured in comparison to blank. By taking $5-100 \mu \mathrm{g} \mathrm{ml}^{-1}$ concentration of standard proline, proline standard curve was set.

\subsubsection{Peroxidase assay}

Leaf tissues $(1 \mathrm{~g})$ were crushed with $0.1 \mathrm{M}$ phosphate buffer $(4 \mathrm{ml})$. The mixture of plant was centrifuged at $4{ }^{\circ} \mathrm{C}$ for $10 \mathrm{~min}$ at $14000 \mathrm{rpm}$. The enzyme estimation was carried out with the supernatant. Test and control reactions were conducted side by side by mixing $0.2 \mathrm{ml}$ enzyme extract with phosphate buffer. Guaiacol solution was added to test reaction and left at room temperature followed by addition of $\mathrm{H}_{2} \mathrm{O}_{2}$. Blank reaction was also performed and optical density of test and control reactions was read against blank. The enzyme units were calculated as methods were described by Racusen and Foote (1965) as units per gram. 


\subsubsection{Acid phosphatase activity}

The extraction of enzyme was carried out following methods of Iqbal and Rafique (1987). Tris $\mathrm{HCl}$ buffer was used to crush the plant material and supernatant obtained was used for enzyme estimation. Acid phosphatase enzyme activity was determined at $\mathrm{pH} 4.9$ for one hour at $37^{\circ} \mathrm{C}$. Series of reactions were carried out for qualitative estimation including control, test, blank and standard. Optical density was measured at $510 \mathrm{~nm}$ wavelength against water and enzyme units were calculated.

\subsubsection{Protein content estimation}

For the estimation of soluble protein content of plant, plant material was homogenized with phosphate buffer using pestle ad mortar and ratio of buffer to plant was $4: 1$. Centrifugation of samples was performed at $4{ }^{\circ} \mathrm{C}$ for $10 \mathrm{~min}$ at $14000 \mathrm{rpm}$. Supernatant $(0.4 \mathrm{ml})$ was mixed with Folin's mixture $(2 \mathrm{ml})$ followed by the addition of Ciocalteu's phenol and Folin reagent after 15 minutes at room temperature. The tubes were placed for 45 minutes at room temperature, after observing color change optical density was read at $750 \mathrm{~nm}$. Results were calculated with the help of standard curve.

\section{Results}

\subsection{Isolation and 16S rRNA sequencing of Bacteria}

Different samples of soil from the rhizosphere of vegetables were collected, bacterial strains able to solubilize phosphate were isolated. Three strains Rad1, $\operatorname{Rad} 2, \operatorname{Ros} 2$ gave promising results as compared to control for phosphate solubilization on PVK as well as NBRIP medium as shown in Table 1. The strains after isolation were directly sent for $16 \mathrm{~S}$ rRNA sequencing using the service of Macrogen, Korea. The sequences retrieved after sequencing were BLAST analyzed and the homology was checked with the test organisms. Analysis showed that the strains belong to Pseudomonas genera (as shown in Table 2).

\subsection{Phosphate solubilization potential}

Phosphate solubilizing potential was measured for the isolated strains as described below.

\subsubsection{Determination of phosphate solubilization index}

The bacterial strains were checked for phosphate solubilization potential by observing clear zones around the bacterial colony as compared to negative control which gave no zone around the growth of bacteria. The strain Rad1 gave zone of $2.27 \mathrm{~mm}$ on PVK and $2.5 \mathrm{~mm}$ on NBRIP medium. Strain Rad2 gave good result on NBRIP medium i.e zone of $2.84 \mathrm{~mm}$ while on PVK medium it gave $2.42 \mathrm{~mm}$. Strain Ros 2 gave good result on PVK medium i.e zone of $2.6 \mathrm{~mm}$ was observed, while on NBRIP medium zone of $2.23 \mathrm{~mm}$ was observed (as shown in Table 1).

\subsubsection{Phosphate estimation}

The three phosphate solubilizing strains were checked for P estimation and were compared with the control. Strain Radl gave good results in NBRIP medium i.e $966 \mu \mathrm{g} \mathrm{ml}^{-1}$ while in PVK medium $126.3 \mu \mathrm{g} \mathrm{ml}^{-1}$ was observed. The most promising results were observed by strain $\operatorname{Rad} 2$ in NBRIP medium i.e $1163.1 \mu \mathrm{g} \mathrm{ml}^{-1}$ while in PVK medium 347.4 $\mu \mathrm{g} \mathrm{ml}^{-1}$ was observed. Strain Ros2 gave values 955.6 and $648.3 \mu \mathrm{g} \mathrm{ml}^{-1}$ in NBRIP medium and PVK medium, respectively (as shown in Table 1).

\subsubsection{Effect of phosphate solubilization on $\mathrm{pH}$ and titrable acidity}

The effect of phosphate solubilization was checked on PVK medium and also in NBRIP medium and was compared with the control. The titrable acidity value for Rad1 in PVK and NBRIP medium observed was 17.2 and 21.3, respectively. Strain Rad2 and Ros2 showed decreased titrable acidity on PVK and increased titrable acidity on NBRIP medium, respectively. Strain Ros2 gave promising results in NBRIP medium (as shown in Table 1).

Table 1. Characterization of phosphate solubilizing bacteria for solubilization potential.

\begin{tabular}{|c|c|c|c|c|c|c|c|c|}
\hline \multirow{2}{*}{$\begin{array}{l}\text { Bacterial } \\
\text { strain }\end{array}$} & \multicolumn{2}{|c|}{ Solubilization index } & \multicolumn{2}{|c|}{$\begin{array}{c}\text { P estimation } \\
(\mu \mathrm{g} / \mathrm{ml})\end{array}$} & \multicolumn{2}{|c|}{ Titrable acidity } & \multicolumn{2}{|c|}{$\mathbf{p H}$} \\
\hline & PVK & NBRIP & PVK & NBRIP & PVK & NBRIP & PVK & NBRIP \\
\hline Control & - & - & - & - & - & - & 7.0 & 7.0 \\
\hline Rad1 & 2.27 & 2.5 & 126.3 & 966.0 & 17.2 & 21.3 & 4.4 & 5.0 \\
\hline $\operatorname{Rad} 2$ & 2.42 & 2.84 & 347.4 & 1163.1 & 8.0 & 22.5 & 4.3 & 4.9 \\
\hline Ros2 & 2.6 & 2.23 & 648.3 & 955.6 & 19.6 & 24.5 & 4.2 & 4.7 \\
\hline
\end{tabular}

PVK: Pikovskaya agar; NBRIP: National Botanical Research Institute Phosphate.

Table 2. Identification of phosphate solubilizing bacterial strains.

\begin{tabular}{ccccc}
\hline Strain code & Isolation source & Location & Identified organism & Accession No. \\
\hline Rad1 & Raphanus sativus & Lahore & Pseudomonas putida & KP241947 \\
Rad2 & Raphanus sativus & Lahore & Pseudomonas sp & KX345931 \\
Ros2 & Rosa indica & Lahore & Pseudomonas fulva & KX345930 \\
\hline
\end{tabular}




\subsubsection{Effect of phosphate solubilization on $\mathrm{pH}$}

The negative log of hydrogen ion $(\mathrm{pH})$ concentration was checked for the phosphate solubilizing bacteria. $\mathrm{pH}$ was measured by using $\mathrm{pH}$ meter. Strains were compared with the control $\mathrm{pH}$ i.e 7. Strains were highly acidic on both media i.e PVK and NBRIP (as shown in Table 1).

\subsection{PGPR Attributes}

\subsubsection{Ammonia production}

Phosphate solubilizing bacterial strains were checked for ammonia production i.e., development of the brown color was observed by the strains and was compared with the control in which no color change was observed after incubation. Strain Rad1 and Rad2 showed positive results for ammonia production whereas strain Ros2 showed highly positive results for ammonia production (as shown in Table 3).

\subsubsection{HCN production}

All the three strains were also evaluated for $\mathrm{HCN}$ production ability. The color change of filter paper by the strains was observed (i.e., yellow to orange). Strain Rad1 showed slight activity while strain Rad 2 was highly positive for HCN production. Strain Ros 2 showed negative results (as shown in Table 3 ).

\subsubsection{Siderophore production}

For siderophore production, method of Schwyn and Neilands (1987) was followed and bacteria were grown on blue agar. The strains were evaluated for siderophore production ability. Strains Rad1 and Rad2 were negative for siderophore production while strain Ros2 was highly positive for siderophore production (as shown in Table 3).

\subsubsection{Auxin estimation}

The strains were evaluated for auxin production in the L- tryptophan presence. Production of pink color was observed after incubation, by the strain. The results obtained by the strains $\operatorname{Rad} 1, \operatorname{Rad} 2$ and $\operatorname{Ros} 2$ were $33.1,30.67$ and $15.38 \mu \mathrm{g} \mathrm{ml}^{-1}$ auxin, respectively. Maximum auxin production was observed by strain Rad1 (as shown in Table 3).

\subsubsection{ACC deaminase activity}

The phosphate solubilizing bacterial strains were evaluated for ACC deaminase production. Strains Rad1, $\operatorname{Rad} 2$ and Ros 2 showed ACC deaminase activity of 0.359 , 0.301 and $0.278 \mathrm{mmol} \mathrm{ml}^{-1}$, respectively. The strain Ros2 showed decreased activity of ACC deaminase. Maximum activity was observed by strain Rad1 (as shown in Table 3 ).

\subsection{Effect of pesticide stress on root elongation assay}

Maximum increase (16\%) in the percentage germination under pesticide stress was observed by strain Rad1 as compared to its respective noninoculated control (see Figure 1a). With the application of strains and independent or combination of fertilizers to wheat showed significant increase in its growth as compared to noninoculated control. $88 \%$ increase in root length and $33 \%$ increase in shoot length of wheat was observed in the presence of strain Ros 2 and treatment group 2 in comparison to control. (see Figure $1 \mathrm{~b}$ and 1c). There was significant $6 \%$ increase in no. of roots of wheat by strain $\operatorname{Rad} 2$ and treatment group 1 (see Figure 1d).

\subsection{Plant biochemical tests}

\subsubsection{Acid phosphatase test}

Strain Rad2 showed good results as compared to control with stress and without stress i.e., 0.7 and 0.5 K.A units $100 \mathrm{ml}^{-1}$, respectively. Strain Rad1 showed no prominent results as compared to control. Strain Ros 2 showed decreased activity i.e., $0.15 \mathrm{~K}$.A units $100 \mathrm{ml}^{-1}$ with stress and $0.4 \mathrm{~K}$.A units $100 \mathrm{ml}^{-1}$ without stress (see Figure 2a).

\subsubsection{Chlorophyll content estimation}

Reduction in chlorophyll content was observed for isolates Rad1, Rad2 and Ros2 under pesticide stress as compared to noninoculated control. Strains Rad1 and Rad2 were found to be the most effective isolates which gave values upto $6 \mathrm{mgg}^{-1}$ for carotenoids over noninoculated control (see Figure 3).

\subsubsection{Peroxidase test}

Peroxidase activity increased in stress conditions in case of all three strains. The most promising results were obtained by strain Rad2 i.e., 72 unit gram ${ }^{-1}$ without stress and 79 unit gram $^{-1}$ with stress. Strain Ros 2 showed results 60 unit gram ${ }^{-1}$ without stress and 73 unit gram $^{-1}$ with stress. Strain Rad1 showed 58 unit gram $^{-1}$ without stress and

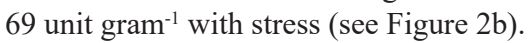

\subsubsection{Proline content estimation}

All the strains showed decreased proline activity as compared to control. There was an increased activity of proline with stress by all the strains as compared to the treatment without stress (see Figure 2c).

Table 3. Plant growth promoting activities of phosphate solubilizing bacteria.

\begin{tabular}{cccccc}
\hline $\begin{array}{c}\text { Bacterial } \\
\text { strain }\end{array}$ & $\begin{array}{c}\text { Ammonia } \\
\text { production }\end{array}$ & HCN & $\begin{array}{c}\text { Siderophore } \\
\text { production }\end{array}$ & Auxin estimation & ACC deaminase \\
\hline Rad1 & + & + & - & 33.1 & $(\mathbf{m m o l} / \mathbf{m l})$ \\
Rad2 & + & +++ & - & 30.67 & 0.359 \\
Ros2 & ++ & - & +++ & 15.38 & 0.301 \\
\hline
\end{tabular}

+ slight; ++ moderate; +++ strong. 

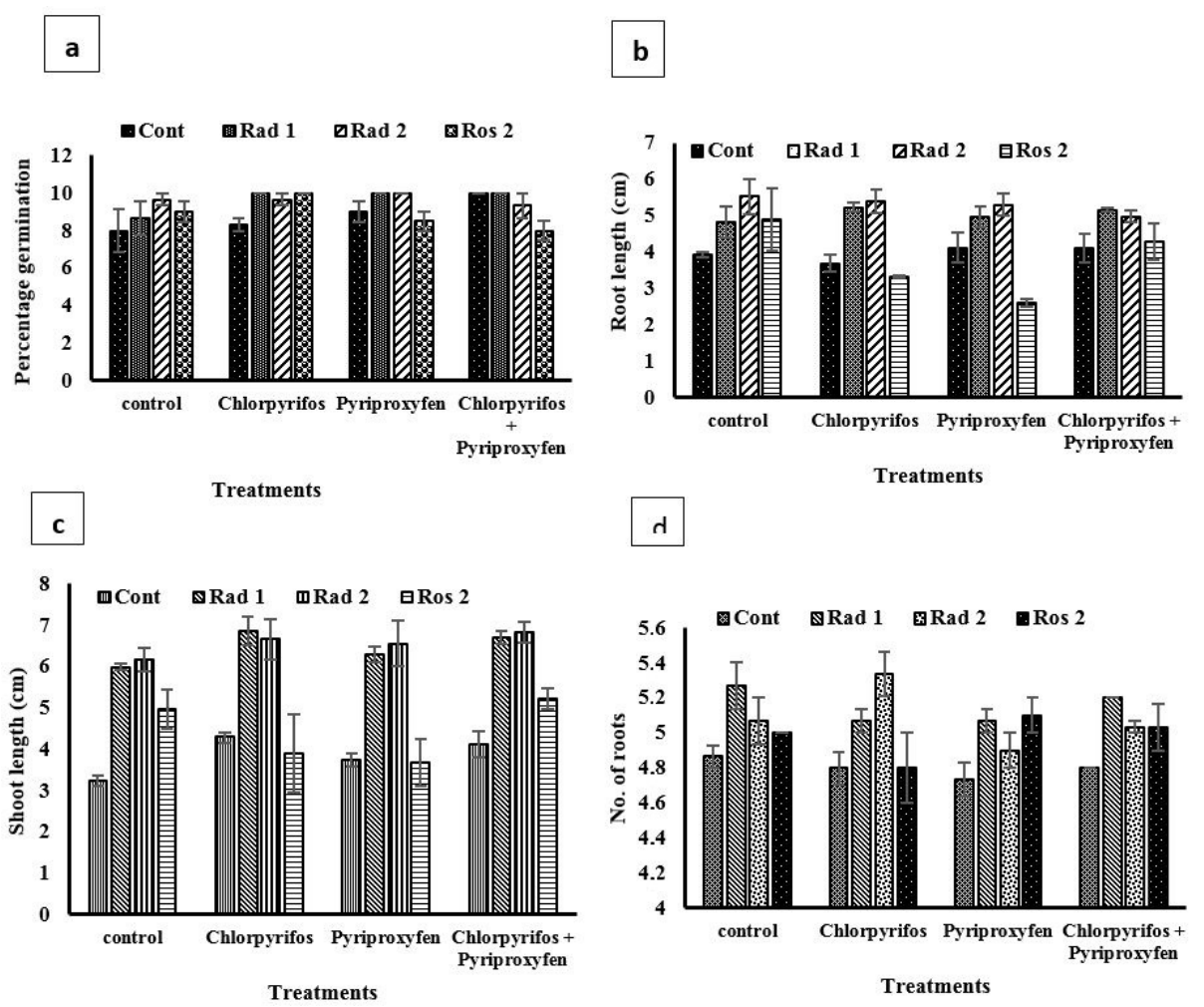

Figure 1. Effect of phosphate solubilizing Pseudomonas inoculation and pesticide stress on germination of Triticum aestivum (a) percentage germination, (b) root length, (c) shoot length, (d) number of roots.
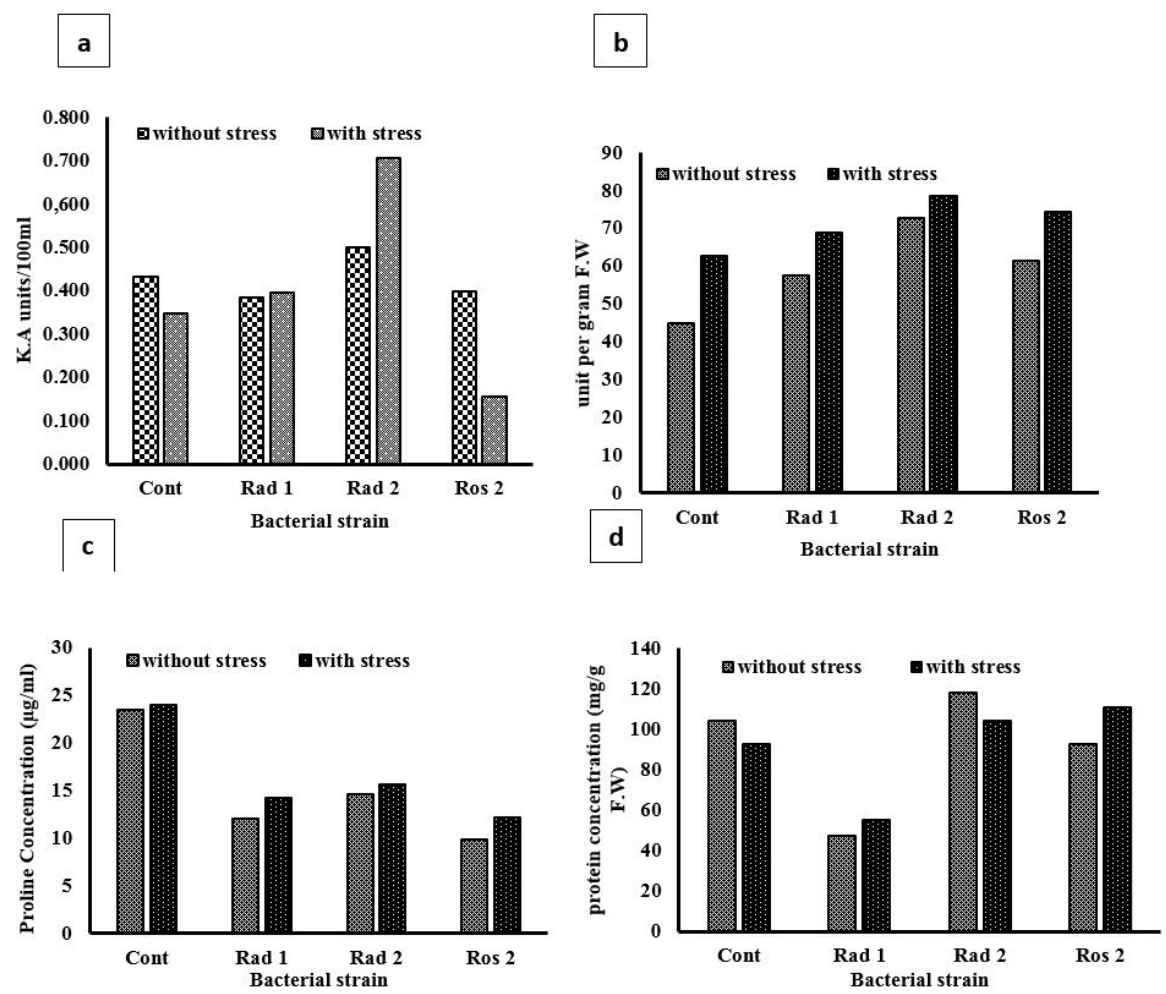

Figure 2. Effect of phosphate solubilizing Pseudomonas strain inoculation (a) acid phosphatase activity, (b) peroxidase activity, (c) proline concentration, (d) protein estimation of Triticum aestivum with and without pesticide stress. 


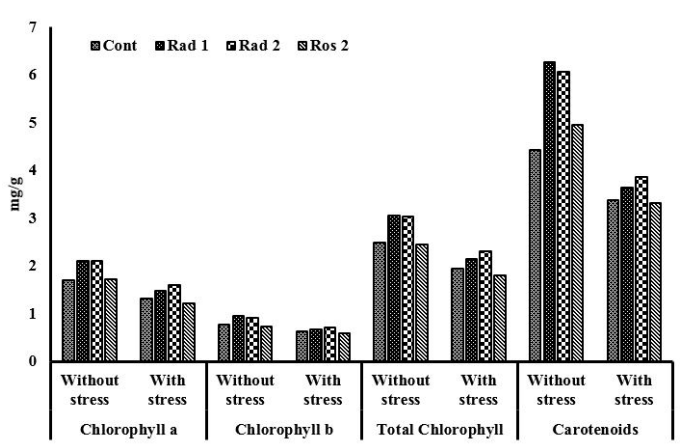

Figure 3. Effect of phosphate solubilizing Pseudomonas strain inoculation on chlorophyll content of Triticum aestivum with and without pesticide stress.

\subsubsection{Protein estimation}

Protein concentration was estimated for the wheat plant treated with pesticide stress in the presence of bacterial inoculum and the results were compared with control. Soluble protein content increased under pesticide stress i.e., $55 \mathrm{mg} \mathrm{g}^{-1}$ by strain Rad1 and $110 \mathrm{mg} \mathrm{g}^{-1}$ by strain Ros2 as compared to its control while protein concentration was decreased in the stress condition i.e $100 \mathrm{mg} \mathrm{g}^{-1}$ by strain $\operatorname{Rad} 2$ as compared to its control. (see Figure 2d).

\section{Discussion}

Microorganisms are present in different habitats like air, soil and water. They interact differently with host microorganisms, other microorganisms and their physiochemical environment (Reche and Fiuza, 2005). Isolation of bacteria able to solubilize phosphate from the rhizosphere of plants Rhapanus sativus and Rosa indica was done and were identified as Pseudomonas putida, Pseudomonas sp. and Pseudomonas fulva. These bacterial strains were tested in the presence of pesticide (pyriproxyfen and chlorpyrifos). Field trial was performed in the Microbiology and Molecular Genetics Department with the wheat (Triticum aestivum) plant under the stress condition. Bacterial strains P. aeruginosa, P. stutzer, $P$. chlororaphis and $P$. fluorescens are non-pathogenic biocontrol agents, also show plant growth-promoting activities (Parray et al., 2016). Pseudomonas genus give plant protection against pests, plant growth stimulation or bioremediation (Daval et al., 2011).

Phosphate solubilizing Strain Rad1 gave good results for solubilized phosphate estimation in NBRIP medium i.e., $966 \mu \mathrm{g} \mathrm{ml}^{-1}$ while in PVK medium $126.3 \mu \mathrm{g} \mathrm{ml}^{-1}$ was observed. The most promising results were observed by strain $\operatorname{Rad} 2$ in NBRIP medium i.e., $1163.1 \mu \mathrm{g} \mathrm{ml}^{-1}$ while in PVK medium $347.4 \mu \mathrm{g} \mathrm{ml}^{-1}$ of solubilized phosphate was recorded. All the strains showed decrease in $\mathrm{pH}$ after inoculation and phosphate solubilization in both medium i.e., PVK and NBRIP. Decrease in the $\mathrm{pH}$ after solubilization of phosphate in PVK growth medium was also reported. $\mathrm{pH}$ reduction indicates the production of different types of acids like gluconic acid, citric and propionic acid etc. and acidification caused by metabolic processes play important role in phosphate solubilization (Kumar et al., 2016). According to the study conducted by Rodríguez and Fraga (1999), similar results have been reported where Rhizobia, Bacillus and Pseudomonas were able to solubilize phosphate.

According to the study done by El-Azeem et al. (2007), insoluble mineral phosphate solubilization between the range of 1.53 to $360 \mu \mathrm{g} \mathrm{mL}^{-1}$ and also the $\mathrm{pH}$ reduction from normal value of 7.1 to the range between 4.16 and 6.45 was reported. Strain Rad1 and Rad2 showed positive results for ammonia production while strain Ros 2 showed strong positive results for ammonia production. Strain Rad1 showed slight activity while strain $\operatorname{Rad} 2$ was highly positive for HCN production. Strain Ros2 was highly positive for siderophore production. For IAA the results obtained by the strains Rad1, Rad2 and Ros2 were 33.1, 30.67 and $15.38 \mu \mathrm{g} \mathrm{ml}^{-1}$, respectively. Study showed low production of IAA by Pseudomonas sp. i.e., below $40.0 \mu \mathrm{g} \mathrm{mL}^{-1}$ (Anjum et al., 2011). The Solubilization Index (SI) was 2.7 for both of the strains of Pseudomonas (Ehsan et al., 2016). ACC deaminase activity observed by the strains Rad1, Rad2 and Ros2 showed results 0.359, 0.301 and $0.278 \mathrm{mmol} \mathrm{ml}^{-1}$, respectively. The strain Ros 2 showed decreased activity of ACC deaminase. Study conducted by Ehsan et al. (2016) showed production of IAA by Pseudomonas strains in the range $54 \%$ to $88 \%$.

In the presence of treatment group 3, strains Rad1, $\operatorname{Rad} 2$ and Ros 2 showed percentage germination $16 \%$, $3 \%$ and $12 \%$. Strain Rad1 showed promising results in the presence of all the three treatment groups. When treatment group 1 was applied strain Ros 2 showed 48\% increase in root length while strains Rad 1 and $\operatorname{Rad} 2$ showed no significant increase in root length. In the presence of treatment group 3, strains $\operatorname{Rad} 1, \operatorname{Rad} 2$ and $\operatorname{Ros} 2$ showed $13 \%, 11 \%$ and $6 \%$ increase in shoot length. The strains activity was compared with the control. Strain Rad2 showed good results for phosphatase as compared to control with stress and without stress i.e., 0.7 K.A units $100 \mathrm{ml}^{-1}$ and $0.5 \mathrm{~K}$.A units $100 \mathrm{ml}^{-1}$, respectively. Most promising results were obtained for carotenoids production upto $6 \mathrm{mg} \mathrm{g}^{-1}$ without stress by strains $\operatorname{Rad} 1$ and $\operatorname{Rad} 2$. Under stress conditions all the strains $(\operatorname{Rad} 1, \operatorname{Rad} 2$ and Ros2) produced carotenoids for upto 3.5, 3.6 and 3.2 mg $\mathrm{g}^{-1}$ of fresh weight, respectively. Strain Ros 2 showed results 60 unit gram ${ }^{-1}$ without stress and 73 unit gram $^{-1}$ with stress. Strain Rad1 showed 58 unit gram ${ }^{-1}$ without

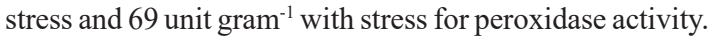
Increase activity of proline was observed with stress by all the strains as compared to without stress. Strain $\operatorname{Rad} 2$ gave most promising results $120 \mathrm{mg} \mathrm{g}^{-1}$ without stress and $100 \mathrm{mg} \mathrm{g}^{-1}$ with stress for protein estimation. Strain Ros2 gave results $90 \mathrm{mg} \mathrm{g}^{-1}$ without stress and $110 \mathrm{mg} \mathrm{g}^{-1}$ with stress. Use of pesticides help in causing bacteriostatic effect on microorganisms (Botelho et al., 2012). According to the study, the maximum toxicity by pesticide pyriproxyfen was observed to nodule numbers in pea, root and shoot dry 
biomass, shoot nitrogen and root phosphorus in greengram, leghaemoglobin, seed protein and chlorophyll content in chickpea. Root nitrogen, odule biomass root phosphorus, shoot phosphorus effects were also observed (Ahemad and Kibret, 2014).

\section{Acknowledgements}

This work was supported by Higher Education Commission (HEC) and Department of Microbiology and Molecular Genetics, University of the Punjab, Lahore, Pakistan.

\section{References}

ABBAMONDI, G.R., TOMMONARO, G., WEYENS, N., THIJS, S., SILLEN, W., GKOREZIS, P., IODICE, C., RANGEL, W.M., NICOLAUS, B. and VANGRONSVELD, J., 2016. Plant growth-promoting effects of rhizospheric and endophytic bacteria associated with different tomato cultivars and new tomato hybrids. Chemical and Biological Technologies in Agriculture, vol. 3, no. 1, pp. 1-10. http://dx.doi.org/10.1186/s40538-015-0051-3.

AHEMAD, M. and KIBRET, M., 2014. Mechanisms and applications of plant growth promoting rhizobacteria: current perspective. Journal of King Saud University-Sci, vol. 26, no. 1, pp. 1-20. http://dx.doi.org/10.1016/j.jksus.2013.05.001.

AHMAD, M., AKHTAR, M.F.U.Z., JAMIL, M., LATIF, M. and AHMAD, I., 2015. Pesticide tolerant plant growth promoting rhizobacteria isolated from rhizosphere of okra. Soil \& Environment, vol. 32, no. 2, pp. 111-118.

ALHO, C.J.R., 2008. The value of biodiversity. Brazilian Journal of Biology $=$ Revista Brasileira de Biologia, vol. 68, no. 4, suppl. 0, pp. 1115-1118. http://dx.doi.org/10.1590/S151969842008000500018. PMid:19197481.

ANJUM, M.A., ZAHIR, Z.A., ARSHAD, M. and ASHRAF, M., 2011. Isolation and screening of rhizobia for auxin biosynthesis and growth promotion of mung bean (Vigna radiata $L$.) seedlings under axenic conditions. Soil \& Environment, vol. 30, no. 1, pp. 18-26.

ARNON, D.I., 1949. Copper enzymes in isolated chloroplasts. Polyphenoloxidase in Beta vulgaris. Plant Physiology, vol. 24, no. 1, pp. 1-15. http://dx.doi.org/10.1104/pp.24.1.1. PMid:16654194.

BOTELHO, R., FROES, C. and SANTOS, J., 2012. Toxicity of herbicides on Escherichia coli growth. Brazilian Journal of Biology $=$ Revista Brasileira de Biologia, vol. 72, no. 1, pp. 141-146. http://dx.doi.org/10.1590/S1519-69842012000100016. PMid:22437394.

CAPPUCCINO, J. and SHERMAN, N., 2005. Microbiology: $a$ laboratory manual. 6th ed. Ontario: Pearson Education.

CASTRIC, K.F. and CASTRIC, P.A., 1983. Method for rapid detection of cyanogenic bacteria. Applied and Environmental Microbiology, vol. 45, no. 2, pp. 701-702. PMid:16346217.

DAVAL, S., LEBRETON, L., GAZENGEL, K., BOUTIN, M., GUILLERM-ERCKELBOUDT, A.Y. and SARNIGUET, A., 2011. The biocontrol bacterium Pseudomonas fluorescens Pf29Arp strain affects the pathogenesis-related gene expression of the take-all fungus Gaeumannomyces graminis var. tritici on wheat roots. Molecular Plant Pathology, vol. 12, no. 9, pp. 839-854. http://dx.doi.org/10.1111/j.1364-3703.2011.00715.x. PMid:21726382.
EHSAN, M., AHMED, I., HAYAT, R., IQBAL, M., BIBI, N. and KHALID, N., 2016. Molecular identification and characterization of phosphate solubilizing Pseudomonas sp. isolated from rhizosphere of mash bean (Vigna Mungo L.) for growth promotion in wheat. Journal of Agricultural Science and Technology, vol. 18, no. 3, pp. 775-788.

EL-AZEEM, S., MEHANA, T. and SHABAYEK, A., 2007. Some plant growth promoting traits of rhizobacteria isolated from Suez Canal region. In 8th African Crop Science Conference Proceedings, 27-31 October 2007, El-Minia, Egypt. El-Minia, Egypt: ACSS, pp. 1517-1525

GORDON, S.A. and WEBER, R.P., 1951. Colorimetric estimation of indoleacetic acid. Plant Physiology, vol. 26, no. 1, pp. 192-195. http://dx.doi.org/10.1104/pp.26.1.192. PMid:16654351.

IQBAL, J. and RAFIQUE, N., 1987. Toxic effects of bac12 on germination, early seedling growth, soluble-proteins and acidphosphayases in Zea-mays-L. Pakistan Journal of Botany, vol. 19 , no. 1, pp. 1-8.

JACKSON, M., 1973. Soil chemical analysis. New Delhi: Prentice-Hall of India Pvt Ltd.

JETIYANON, K., 2015. Multiple mechanisms of Enterobacter asburiaestrain RS83 for plant growth enhancement. Songklanakarin Journal of Science and Technology, vol. 37, no. 1, pp. 29-36.

KUMAR, A., KUMAR, V. and TRIPTI, T., 2015. Effect of commercial pesticides on plant growth-promoting activities of Burkholderia sp. strain L2 isolated from rhizosphere of Lycopersicon esculentum cultivated in agricultural soil. Toxicological and Environmental Chemistry, vol. 97, no. 9, pp. 1180-1189. http:// dx.doi.org/10.1080/02772248.2015.1093632.

KUMAR, S. S., DEB, S., BHADORIA, P., MUKHOPADHYAY, D., RAKSHIT, A. and CHOUDHURY, A., 2016. Impact of Pseudomonas putida on available soil phosphorus dynamics and crop productivity under lowland rice ecology. Nature Environment and Pollution Technology, vol. 15, no. 1, pp. 227.

MANGMANG, J.S., DEAKER, R. and ROGERS, G., 2015. Azospirillum brasilense Enhances Recycling of Fish Effluent to Support Growth of Tomato Seedlings. Horticulturae, vol. 1, no. 1, pp. 14-26. http://dx.doi.org/10.3390/horticulturae1010014.

MEDEIROS, J.D., ARAÚJO, L.X., SILVA, V.L., DINIZ, C.G., CESAR, D.E., DEL'DUCA, A. and COELHO, C.M., 2014. Characterization of the microbial community in a lotic environment to assess the effect of pollution on nitrifying and potentially pathogenic bacteria. Brazilian Journal of Biology = Revista Brasileira de Biologia, vol. 74, no. 3, pp. 612-622. http:// dx.doi.org/10.1590/1519-6984.26712. PMid:25296210.

PARRAY, J.A., JAN, S., KAMILI, A.N., QADRI, R.A., EGAMBERDIEVA, D. and AHMAD, P., 2016. Current perspectives on plant growth-promoting rhizobacteria. Journal of Plant Growth Regulation, vol. 35, no. 3, pp. 877-902. http:// dx.doi.org/10.1007/s00344-016-9583-4.

PENROSE, D.M. and GLICK, B.R., 2003. Methods for isolating and characterizing ACC deaminase-containing plant growthpromoting rhizobacteria. Plant Physiology, vol. 118, no. 1, pp. 10-15. http://dx.doi.org/10.1034/j.1399-3054.2003.00086.x. PMid: 12702008 .

PIKOVSKAYA, R., 1948. Mobilization of phosphorus in soil in connection with vital activity of some microbial species. Mikrobiologiya, vol. 17, no. 362, pp. 370. 
RACUSEN, D. and FOOTE, M., 1965. Protein synthesis in dark-grown bean leaves. Canadian Journal of Botany, vol. 43, no. 7, pp. 817-824. http://dx.doi.org/10.1139/b65-091.

RECHE, M. and FIUZA, L., 2005. Distribution and density of bacteria in subtropical flooded rice growing areas in Brazil. Brazilian Journal of Biology $=$ Revista Brasileira de Biologia, vol. 65 , no. 3, pp. 503-511. http://dx.doi.org/10.1590/S151969842005000300016. PMid:16341429.
RODRÍGUEZ, H. and FRAGA, R., 1999. Phosphate solubilizing bacteria and their role in plant growth promotion. Biotechnology Advances, vol. 17, no. 4, pp. 319-339. http://dx.doi.org/10.1016/ S0734-9750(99)00014-2. PMid:14538133.

SCHWYN, B. and NEILANDS, J., 1987. Universal chemical assay for the detection and determination of siderophores. Analytical Biochemistry, vol. 160, no. 1, pp. 47-56. http://dx.doi. org/10.1016/0003-2697(87)90612-9. PMid:2952030. 